\title{
PERAN KODIM 0316/ BATAM DALAM MENJAGA STABILITAS PEMBANGUNAN DI ERA ADAPTASI KEBIASAAN BARU
}

\author{
Bayu Septiansyah ${ }^{1}$ Lukman Munawar $^{2}$ Agustina Setiawan $^{3}$ Zaenal Abidin $^{4}$ \\ Anceu Murniati ${ }^{5}$ Wibowo Ndrahadi ${ }^{6}$ Harky Ristala $^{7}$ \\ Universitas Jenderal Achmad Yani \\ Email: bayu.septiansyah@lecture.unjani.ac.id
}

\begin{abstract}
Abstrak
Keterlibatan Kodim 0316/Batam dalam situasi krisis kesehatan global telah dimulai sejak COVID-19 mewabah di Indonesia, mulai dari penerapan Pembatasan Sosial Berskala Besar hingga penerapan fase adaptasi new normal. Tujuan dalam penelitian ini adalah Untuk mengetahui dan mendeskripsikan Peran Kodim 0316/Batam Dalam Menjaga Stabilitas Pembangunan di Era Adaptasi Kebiasaan Baru. Metode dalam penelitian ini menggunakan penelitian kualitatif, dalam penelitian kualitatif menggunakan metode kualitatif yaitu pengamatan, wawancara dan penelaahan dokumen. Berdasarkan hasil penelitan dapat di simpulkan bahwa Peran Kodim 0316/Batam Dalam Menjaga Stabilitas Pembangunan di Era Adaptasi Kebiasaan Baru, Peran Preventif dalam tindakan preventif satuan kodim sudah melakukan sosialisasi kepada masyarakat tentang kehidupan di era AKB dalam rangka menjaga stabilitas keberhasilan pembangunan nasional, Peran Persuasif Melalui tindakan persuasif satuan kodim dalam melakukan operasi penertiban dan penegakan disiplin masyarakat tentang kehidupan di era AKB dalam rangka menjaga stabilitas pembangunan nasional, Peran Represif Kodim 0316/Batam dalam menjaga dan memelihara kondusifitas pelaksanaan Pembatasan Sosial Berskala Besar (PSBB), melakukan pemberdayaan potensi wilayah sebagai bagian dari pembinaan dan pemberdayaan wilayah pertahanan, serta Peran Kuratif Kodim 0316/Batam sudah berjalan dengan baik.
\end{abstract}

Kata kunci: Adaptasi Kebiasan Baru, Peran, Kodim

\begin{abstract}
The involvement of Kodim 0316 /Batam in a situation of global health crisis has started since the outbreak of COVID-19 in Indonesia, from the implementation of Large-Scale Social Restrictions to the application of the new normal adaptation phase. The purpose of this research is to find out and describe the role of Kodim 0316 / Batam in Maintaining Stability of Development in the Era of Adaptation to New Habits. The method in this study uses qualitative research, in qualitative research using qualitative methods namely observation, interviews and document
\end{abstract}


review. Based on the results of the research, it can be concluded that the Role of Kodim 0316 / Batam in Maintaining Stability of Development in the New Habit Adaptation Era, the Preventive Role in the preventive action of the Kodim unit has carried out socialization to the community about life in the AKB era in order to maintain the stability of the success of national development, Persuasive Role through the persuasive action of the Kodim unit in carrying out policing operations and enforcing community discipline regarding life in the AKB era in order to maintain the stability of national development, the Repressive Role of Kodim 0316 I Batam in maintaining and maintaining conduciveness for the implementation of Large-Scale Social Restrictions (PSBB), empowering regional potentials as part from the guidance and empowerment of the defense area, as well as the curative role of Kodim 0316 / Batam has been going well.

Keywords: Role, Kodim, New Adaptation

\section{PENDAHULUAN}

Penyebaran Covid-19 di Indonesia saat ini sudah semakin meluas lintas wilayah dan lintas negara yang diiringi dengan peningkatan jumlah kasus dan/atau jumlah kematian. Situasi ini kian berdampak pada aspek politik, ekonomi, sosial, budaya, pertahanan, dan keamanan, serta kesejahteraan masyarakat di Indonesia, sehingga diperlukan strategi dan upaya yang komprehensif dalam percepatan penanganan Covid-19.

WHO telah menyatakan Corona Virus Disease 2019 (Covid-19) sebagai sebuah pandemi. Data Worldometers pada tanggal November 2020 menunjukkan, sebanyak 21.817.650 (21,8 juta) orang terinfeksi virus corona di seluruh dunia, dari angka itu, sebanyak 772.751 orang meninggal dunia, dan 14.553 .191 orang telah dinyatakan sembuh. Adapun jumlah kasus aktif yang tercatat saat ini 6.491.708 (6,49 juta) kasus, dengan rincian: 6.427 .223 (6,4 juta) kasus dalam kondisi ringan 64.485 kasus dalam kondisi serius. Pandemi virus corona pun belum menunjukkan tanda-tanda akan mereda, baik dari jumlah kasus maupun kebijakan penanganan yang dilakukan.

Penyebaran Covid-19 di Indonesia saat ini sudah semakin meluas lintas wilayah dan lintas negara yang diiringi dengan peningkatan jumlah kasus dan/atau jumlah kematian. Situasi ini kian berdampak pada aspek politik, ekonomi, sosial, budaya, pertahanan, dan keamanan, serta kesejahteraan masyarakat di Indonesia, 
sehingga diperlukan strategi dan upaya yang komprehensif dalam percepatan penanganan Covid-19.

Selain itu Presiden juga telah menetapkan Keputusan Presiden Nomor 12 Tahun 2020 tentang Penetapan Bencana Non alam Penyebaran Corona Virus Disease 2019 (Covid-19) Sebagai Bencana Nasional, yang menyatakan bahwa penanggulangan bencana nasional yang diakibatkan oleh penyebaran Corona Virus Disease 2019 (Covid-19) dilaksanakan oleh Gugus Tugas Percepatan Penanganan Corona Virus Disease 2019 (Covid-19) dan Gubernur, bupati, dan walikota sebagai Ketua Gugus Tugas Percepatan Penanganan Corona Virus Disease 2019 (Covid19) di daerah dan dalam menetapkan kebijakan di daerah masing-masing harus memperhatikan kebijakan Pemerintah Pusat.

Peraturan Pemerintah Nomor 21 Tahun 2020 tentang Pembatasan Sosial Berskala Besar Dalam Rangka Percepatan Penanganan Corona Virus Disease 2019 (Covid-19) telah menyatakan bahwa Pembatasan Sosial Berskala Besar (PSBB) dilakukan salah satunya dengan meliburkan tempat kerja. Namun demikian dunia kerja tidak mungkin selamanya dilakukan pembatasan, roda perekonomian harus tetap berjalan, untuk itu pasca pemberlakuan PSBB dengan kondisi pandemi Covid19 yang masih berlangsung, perlu dilakukan upaya mitigasi dan kesiapan tempat kerja seoptimal mungkin sehingga dapat beradaptasi melalui perubahan pola hidup pada situasi Covid-19 (New Normal). Dengan menerapkan panduan ini diharapkan dapat meminimalisir risiko dan dampak pandemi Covid-19 pada tempat kerja khususnya perkantoran dan industri, dimana terdapat potensi penularan Covid-19 akibat berkumpulnya sejumlah/banyak orang dalam satu lokasi. Sumber Data: https://lawancorona.batam.go.id/

Menjelang pemberlakuan "new normal" atau Adaptasi Kebiasaan Baru di Kota Batam, Kepulauan Riau (Kepri), pasien corona atau Covid-19 malah terus bertambah. Pertambahan tersebut per hari hampir di atas angka 10. Mereka adalah warga Batam dari hasil tracing atau penyisiran tim kesehatan Batam, mereka tertular dari klaster jemaah HOG serta beberapa klaster lainnya. Tercatat di data infografis Tim Gugus Tugas Covid-19 Kepri, ada 11 pasien positif tambahan baru, sehingga total untuk Batam menjadi 150 kasus dan 218 kasus untuk Kepri. 
Dalam mendukung tugas pemerintah tentang persiapan new normal di Kota Batam, Kodim 0316/Batam menerjunkan maksimal personelnya. Bapak Presiden sebelumnya sudah menegaskan tentang keterlibatan TNI - Polri di kerahkan untuk mengawal dan memastikan masyarakat menjalankan protokol kesehatan di ruang publik, Kodim Batam sendiri tinggal menunggu perintah dari komando atas. Komandam Kodim dan personilnya siap mendukung dan memback up penerapan kebijakan kenormalan baru atau new normal khususnya di Kota Batam, sesuai keputusan Pemerintah Pusat dalam persiapan tatanan kehidupan baru ke depan. Selain itu, Kodim 0316/Batam juga akan bersinergi bersama dengan komponen bangsa lainnya. Termasuk kelompok pelaku ekonomi, perdagangan, dinas kesehatan, serta tenaga pengamanan di lokasi setempat.

Berdasarkan latar belakang masalah maka dilakukan penelitian tentang Peran Kodim 0316/Batam dalam menjaga stabilitas pembangunan di Era Adaptasi Kebiasaan Baru. Adapun yang menjadi rumusan masalah dalam penelitian ini ialah Bagaimana Peran Kodim 0316/Batam dalam menjaga stabilitas pembangunan di Era Adaptasi Kebiasaan Baru. Adapun tujuan penelitian ini ialah untuk mengetahui dan mendeskripsikan Peran Kodim 0316/Batam dalam menjaga stabilitas pembangunan di Era Adaptasi Kebiasaan Baru.

Penelitian ini menggunakan pendekatan deskriptif, proses penelitian kualitatif bersifat seni, dan disebut sebagai metode interpretive karena data hasil penelitian berkenaan dengan interprestasi terhadap data yang ditemukan dilapangan (Sugiyono, 2013). Lebih lanjut (Sugiyono, 2013) menjelaskan bahwa metode penelitian kualitatif digunakan pada kondisi objek yang alamiah dimana peneliti sebagai instrumen kunci. Oleh karena itu penelitian ini lebih menekankan pada metode atau pendekatan penelitian deskriptif kualitatif.

Penelitian yang dilakukan ini bertempat di wilayah Batam Kepri. Waktu penelitian adalah rentang waktu yang digunakan selama proses penyusunan proposal hingga penelitian berlangsung, mulai dari tahap persiapan sampai pada tahap penyusunan laporan sesuai dengan sasaran penelitian.

Pengumpulan data dalam penelitian ini peneliti akan menggunakan prosedur pengumpulan data antara lain : Observasi, dengan cara ini peneliti dapat meyakini, 
dapat melihat dan dapat mengamati sendiri yang kemudian dilanjutkan dengan pencatatan perilaku serta kejadian sebagai mana adanya. Wawancara, melakukan wawancara langsung kepada semua pihak yang berkompoten dalam penelitian ini, agar informasi yang didapatkan tidak meragukan dan dapat dipertanggung jawabkan. Dokumentasi, dokumentasi yakni pengumpulan data dari sumbersumber non visual yakni berupa dokumen-dokumen atau arsip-arsip dan rekaman yang ada relevansinya dengan kebutuhan data yang dibutuhkan peneliti.

\section{PEMBAHASAN}

Peran TNI dalam penanggulangan bencana tertuang dalam Undang-undang TNI Nomor 34 tahun 2004 tentang Tentara Nasional Indonesia, tugas pokok TNI adalah menegakkan kedaulatan negara, mempertahankan keutuhan wilayah Negara Kesatuan Republik Indonesia berdasarkan Pancasila dan UUD 1945 serta melindungi segenap bangsa dan seluruh tumpah darah Indonesia dari ancaman dan gangguan terhadap keutuhan bangsa dan negara. Tugas Pokok TNI tersebut dilakukan dengan menggunakan operasi militer untunk perang dan operasi militer selain perang.

Salah satu tugas TNI dalam melaksanakan operasi militer selain perang adalah membantu menanggulangi akibat bencana alam, pengungsian dan pemberian bantuan kemanusiaan. Maka, Presiden sebagai Panglima tertinggi tidak perlu ragu untuk memberi instruksi kepada Panglima TNI dan Kepala Daerah untuk menyusun rencana kontijensi dalam menghadapi krisis yang mungkin ditimbulkan oleh pandemi Covid-19 ini yakni dengan memetakan kekuatan TNI-Pemda dalam menangani dampak turunan pandemi Covid-19 di Daerah. Dalam rangka pelaksanaan tugas perbantuan TNI AD kepada pemerintah di daerah diperlukan kebijakan Kementrian Pertahanan yang mengatur pelaksanaan tugas perbantuan dalam menangani permasalahan tersebut antara lain membantu mengatasi pandemi Covid-19, rehabilitasi infrastruktur, mengatasi akibat pemogokan dan konflik komunal serta tugas-tugas lain sesuai kebutuhan pemerintah di daerah. Keadaan ini bila tidak diatasi dengan cepat, komprehensif dan terpadu akan merugikan masyarakat secara meluas, berpeluang terjadinya kelumpuhan pemerintahan dan 
perekonomian, sehingga perlu adanya suatu penanggulangan dan penanganan yang tepat.

Dalam hal ini, peningkatan Dalam Menjaga Stabilitas Pembangunan di Era Adaptasi Kebiasaan Baru sangat dibutuhkan oleh Satuan Pelaksana di Daerah. Kapasitas yang dimaksud adalah kesiapan TNI AD Khususnya Kodim serta soliditas dan sinergitas antara Kodim dengan Pemerintah Daerah dan Polri dalam Menjaga Stabilitas Pembangunan di Era Adaptasi Kebiasaan Baru guna mengawal pembangunan nasional di daerah, khususnya Daerah Batam. Dalam penelitian ini akan dibahas tentang : (a) Bagaimana peran satkowil bersama komponen bangsa lainnya dalam menjaga stabilitas pembangunan di era adaptasi kebiasaan baru.(b) Bagaimana hambatan yang dihadapi satkowil bersama komponen bangsa lainnya dalam menjaga stabilitas pembangunan di era adaptasi kebiasaan baru.

Untuk itu peneliti akan menguraikan hasil penelitian dari hasil wawancana dan studi dokumentasi yang berkaitan dengan rumusan masalah yang diuraikan diatas yaitu dijabarkan sebagai berikut :

\section{A. Peran Preventif}

Kodim Kodim 0316/Batam dalam rangka mempersiapkan personil kodim yang siap dalam rangka membantu tugas-tugas pemerintah khsusunya dalam menjaga stabilitas pembangunan di era adaptasi kebiasaan baru dilaksanakan sesuai petunjuk TNI AD. Personil kodim pada dasarnya telah melaksanakan tugas secara preventif yang harus dilaksanakan dalam rangka menjaga stabilitas pembangunan di era adaptasi kebiasaan baru di Batam, hal ini sesuai dengan hasil wawancara dengan Komandan Kodim 0316/Batam Letkol Kav Sigit Dharma Wiryawan, SH bahwa : "dalam tindakan preventif satuan kodim sudah melakukan sosialisasi kepada masyarakat tentang kehidupan di era AKB dalam rangka menjaga stabilitas keberhasilan pembangunan nasional".

Bahkan kodim telah melaksanakan sosialisasi dari Bulan Mei hingga sekarang. Sejalan dengan pernyataan Dandim 0316/Batam hasil wawancara dengan Walikota Batam H. M. Rudi, SE., MM bahwa :

"sosialisasi dilaksanakan dengan baik bersama tim gugus tugas Covid-19 kota batam secara terpadu, kegiatan dilaksanakan secara patrol untuk pemberitahuan masa tentang protocol kesehatan di era AKB di seluruh 
wilayah di kota batam (12 kecamatan) terutama di tempat yang berpotensi mengumpulkan masa".

Dalam bidang pendidikan rencana proses belajar mengajar tatap muka yang semula akan dimulai pada awal agustus, namun dibatalkan karena terjadi peningkatan kembali angka positif Covid-19 di Kota Batam. Hal tersebut sebagaimana yang disampaikan oleh Dinas Pendidikan Kota Batam.

Untuk mengurangi kemungkinan tertular virus corona, serta mendukung pelaksanaan kehidupan di era AKB dalam rangka menjaga stabilitas keberhasilan pembangunan nasional ada baiknya bila kita sama-sama waspada dan melakukan tindakan preventif sesuai dengan anjuran pemerintah dan badan kesehatan dunia, seperti:

1. Hindari keramaian, bepergian ke tempat umum, atau traveling ke negara terjangkit Covid-19;

2. Kurangi kontak fisik, termasuk untuk urusan pembayaran;

3. Cuci tangan dan lakukan sterilisasi secara berkala terhadap barang yang sering kamu pegang;

4. Menjaga kesehatan dengan berolahraga, perbanyak konsumsi makanan sehat seperti sayur, buah, dan multivitamin;

5. Waspada tentu diperlukan, namun pastikan kamu tidak panik hingga menumpuk stok bahan makanan secara berlebihan;

6. Update diri dengan berita resmi dari pemerintah dan media tepercaya.

Kodim 0316/Batam setelah mendapatkan informasi yang diperoleh tentang tahapan prosedur AKB dalam menjaga stabilitas keberhasilan pembangunan nasional, yaitu melakukan pengarahan dan sosialisasi secara internal. Adapun pengarahan dan sosialisasi diberikan kepada personil yang meliputi Para Pasi, para Komandan Koramil dan Para Babinsa. Sosialisasi dan pengarahan disampaikan terkait tahapan pelaksanaan kehidupan di era AKB dalam rangka menjaga stabilitas keberhasilan pembangunan nasional. Adapun pelaksanaan pemberian pengarahan itu sendiri dilakukan oleh Komandan Kodim baik di Markas Kodim dan juga di Markas Koramil masing-masing. 


\section{B. Peran Persuasif}

Pelaksanaan bantuan Kodim 0316/Batam dalam menanggulangi akibat masa pandemik Covid-19 ini meliputi kegiatan inventarisasi, distribusi, dislokasi, bantuan pengamanan kodim dalam bantuan kemanusiaan. Undang-Undang No.3 Tahun 2003 tentang Pertahanan Negara Pasal 10 ayat 3,

a. TNI bertugas melaksanakan kebijakan pertahanan negara.

b. (butir c): melaksanakan OMSP, antara lain :

1. Bantuan kemanusiaan

2. Perbantuan kepada POLRI dalam kamtibnas

3. Bantuan kepada pemerintahan sipil

4. Pengamanan pelayaran dan penerbangan

5. Bantuan SAR

6. Penanggulangan bencana alam

c. OMSP dilakukan berdasarkan permintaan dan/atau peraturan perundangan.

Melalui tindakan persuasif satuan kodim dalam melakukan operasi penertiban dan penegakan disiplin masyarakat tentang kehidupan di era AKB dalam rangka menjaga stabilitas pembangunan nasional sangatlah diperlukan. Para prajurit tentunya sudah memahami dan sangat memahami tugas dan fungsinya selaku TNI AD dalam rangka melaksanakan tugas OMSP. Kodim sebagai bagian dari kegiatan pilkada tentunya sangat paham dan profesional dalam bidang militer dan kemampuan membantu penanganan bencana, namun tentunya bukan berarti tidak memiliki kendala atau hambatan, hambatan ini biasanya terkait dengan kemampuan pengetahuan para personil terhadap penanganan Covid-19 dan terkait dengan regulasi, prosedur serta batas-batas kewenangan dalam penanganan Covid19. Sebagaimana wawancara yang dilakukan dengan Komandan Kodim 0316/Batam bahwa :

"kodim dalam melaksanakan operasi penertiban dan penegakan displin masyarakat tentang kehidupan di era AKB sudah melaksanakan secara persuasif bekerjasama dengan instansi tertai secara terpadu, adapun sasaran operasi di pusat keramaian meliputi bandara, pelabuhan, mall, pasar, industri dan perumahan, pada dasarnya sama saja hambatan nya ialah masih banyaknya pelanggaran dari masyarakat yang belum mematuhin aturan di 
era $\mathrm{AKB}$ ini seperti tidak menggunakan masker serta tidak menjaga jarak ditempat umum".

Berdasarkan pendapat Komandan Kodim jelas bahwa para personil kodim dan jajarannya telah melakukan operasi penegakan displin masyarakat tentang kehidupan di era AKB dengan cara persuasif, adapun hukuman yang saat ini diberikan oleh personel kepada masyarakat yang melakukan pelanggaran hanya di berikan teguran dan sangsi hukuman push up sewajarnya. Tentunya Kodim memiliki kemampuan yang terbatas terkait memberikan penegakan dalam melaksakanan operasi terpadu karena belum adanya aturan yang tegas untuk para pelanggaran, sehingga hukuman yang diberikan masih bersifat persuasif.

\section{Peran Represif}

Suatu aturan yang bersifat memaksa pada saat ini tidak boleh kemudian di pandang sebagai suatu tindakan yang sewenang-wenang dari pemerintah, namun hal ini merupakan tanggung jawab pemerintah dan merupakan perintah dari Konstitusi yakni "melindungi segenap bangsa Indonesia" sebagaimana termuat di dalam alenia ke-4 Pembukaan UUD NRI Tahun 1945. Maka upaya dari pemerintah dengan memaknai esensi dari keberadaan hukum sebagai sarana untuk mengatur masyarakat, yakni sebagai alat untuk merekayasa masyarakat dan sebagai alat kontrol (law is a tool of social engineering and tool of social control) seperti yang dikatakan oleh Roscoue Pound.

Pemerintah Kota Batam telah memberlakukan karantina wilayah per kecamatan sebagai langkah pencegahan penyebaran Covid-19. Tim Gugus Tugas Penanganan Covid-19 Kota Batam akan fokus di 9 kecamatan karena berada di satu lokasi dari 12 kecamatan yang ada di Batam. Sedangkan tiga kecamatan lainnya berada di wilayah pesisir yang wilayahnya merupakan pulau tersendiri akan menyusul. Dari 9 kecamatan yang ada, lima diantaranya merupakan kecamatan yang ditetapkan sebagai wilayah terbanyak sebaran pasien positif Covid-19.

Ketua Tim Gugus Tugas Percepatan Penanganan Covid-19 Kota Batam, Muhammad Rudi tidak menjelaskan secara detail kecamatan mana saja yang menjadi wilayah terbanyak sebaran pasien Covid-19 tersebut. Namun pada prosesnya, 5 kecamatan ini akan ditangani semaksimal mungkin. Sebagaimana 
wawancara yang dilakukan dengan ketua Gugus Tugas Percepatan Penanganan Covid-19 Kota Batam bahwa:

"kerja maksimal tim di lapangan, harus didukung masyarakat Batam dengan mengikuti semua imbauan pemerintah. Diantaranya himbauan social dan physical distancing, memakai masker, dan tetap memperbanyak waktu di rumah masing-masing. Seperti diketahui langkah karantina wilayah perkecamatan itu diambil menggantikan Pembatasan Sosial Berskala Besar (PSBB) yang urung diajukan. Secara teknis tim gugus tugas yang terdiri atas lintas instansi ini akan fokus menangani persoalan Covid-19 dari kecamatan yang satu ke kecamatan yang lain yang ada di Kota Batam".

"kodim melakukan pemberdayaan potensi wilayah dalam memelihara kondusifitas pelaksanaan Pembatasan Sosial Berskala Besar (PSBB) dengan memberdayakan para tokoh agama, tokoh masyarakat serta tokoh pemuda yang berada di wilayah".

Kodim 0316/Batam dalam menjaga dan memelihara kondusifitas pelaksanaan Pembatasan Sosial Berskala Besar (PSBB), melakukan pemberdayaan potensi wilayah sebagai bagian dari pembinaan dan pemberdayaan wilayah pertahanan. Pemberdayaan wilayah dilakukan sebagaimana wawancara dengan Komandan Kodim bahwa:

Dalam masa pelaksanaan Pembatasan Sosial Berskala Besar (PSBB) di Batam masih banyak pelanggaran yang dilakukan oleh masyarakat di Batam, Sebagaimana wawancara yang dilakukan dengan Komandan Kodim 0316/Batam bahwa:

"selama operasi penegakan disiplin masyarakat penyimpangan yang dilakukan oleh masyarakat tentang kehidupan di era AKB masa Pembatasan Sosial Berskala Besar (PSBB) masih banyak yang tidak patuh memakai masker, serta tidak menjaga jaga jarak di tengah kerumunan”.

Kodim 0316/Batam selaku penyelenggara fungsi binter di daerah Kota Batam, Kepri, bersama-sama institusi pemerintah dan komponen masyarakat secara terencana, terpadu, sistematis dan terarah, mewujudkan potensi kewilayahan yang didayagunakan dan diarahkan untuk mewujudkan kesejahteraan masyarakat serta terciptanya ketahanan wilayah. Kodim bertugas pokok menyelenggarakan pembinaan kemampuan, kekuatan dan gelar kekuatan, menyelenggarakan pembinaan teritorial untuk menyiapkan wilayah pertahanan di darat dan menjaga keamanan wilayahnya dalam rangka mendukung tugas pokok Kodam/Korem. 
Kodim 0316/Batam dalam rangka mempersiapkan personil kodim yang siap dalam rangka membantu tugas-tugas pemerintah daerah khsusunya dalam stabilitas keamanan daerah. Sehingga pelaksanaan program pembagunan dapat terselenggara dengan baik dalam kehidupan di era AKB guna menjaga stabilitas keberhasilan pembangunan nasional dilaksanakan sesuai petunjuk TNI AD.

\section{Peran Kuratif}

Peran Kuratif, suatu kegiatan dan/atau serangkaian kegiatan pengobatan yang ditujukan untuk penyembuhan penyakit, pengurangan penderitaan akibat penyakit, pengendalian penyakit, atau pengendalian kecacatan agar kualitas penderita dapat terjaga seoptimal mungkin. Setelah tiga bulan berupaya mengendalikan penularan wabah Covid-19 melalui karantina wilayah, pemerintah Indonesia akhirnya memilih kembali menjalankan roda perekonomian yang sempat lesu, termasuk membuka tempat ibadah dan mal. Pemerintah mengkampanyekan normal baru. Istilah ini merujuk pada sebuah tatanan baru yang menganjurkan perilaku hidup bersih dan sehat dengan pelaksanaan protokol kesehatan yang lebih ketat untuk masyarakat dan fasilitas umum guna mencegah penularan virus corona. Dalam pandemi Covid-19, Kodim 0316/Batam mempunyai peran yang sangat penting mulai dari promotif, preventif, kuratif sampai rehabilitatif. Sebagaimana wawancara yang dilakukan dengan Komandan Kodim 0316/Batam bahwa:

"Promotif: melakukan berbagai pendekatan ke masyarakat agar masyarakat mengerti tanda, gejala serta bahaya dari Covid-19. Preventif: menskrining Covid-19 di wilayah kerjanya dengan bekerja sama dengan dokter praktik/klinik/bidan praktik. Mereka juga perlu memantau orang-orang tanpa gejala (OTG), orang dalam pemantauan (ODP) atau pasien dalam pengawasan (PDP) dengan gejala ringan. Kuratif: mengobati pasien OTG, ODP dan PDP dengan gejala ringan sehingga mereka dapat sembuh tanpa harus ke rumah sakit. Rehabilitatif: memberikan konseling ke keluarga dan lingkungan di dekat penderita Covid agar tidak mengucilkan pasien Covid19, sebaliknya memberi dukungan pada pasien Covid-19 dan keluarganya".

Kerja sama yang erat antara Kodim 0316/Batam dan masyarakat akan meningkatkan kepatuhan pada protokol kesehatan serta mengurangi hambatan dalam upaya penanggulangan Covid-19 yang berasal dari masyarakat. Salah satunya keengganan masyarakat untuk dites Covid-19 secara gratis, karena 
ketakutan tidak bisa beraktivitas seperti biasa dan stigma dari masyarakat setempat jika hasilnya positif.

\section{Analisis SWOT Peran Kodim 0316/Batam Dalam Menjaga Stabilitas Pembangunan Di Era Adaptasi Kebiasaan Baru}

Untuk menjawab rumusan masalah yang telah gambarkan atau dideskripsikan pada pembahasan sebelumnya, maka dalam penjelasan selanjutnya peneliti menggunakan analisa SWOT. Analisa ini berguna untuk memudahkan peneliti dalam menjabarkan Peran Kodim 0316/Batam Dalam Menjaga Stabilitas Pembangunan Di Era Adaptasi Kebiasaan Baru.

\section{Tabel. Matrik Interaksi Faktor Internal dan Eksternal}

\begin{tabular}{|c|c|}
\hline Faktor Internal & Faktor Eksternal \\
\hline Kekuatan & Peluang \\
\hline $\begin{array}{l}\text { a. Sesuai dengan UU RI No. } 34 \text { tahun } 2004 \\
\text { tentang TNI bertugas pokok melaksanakan operasi } \\
\text { militer perang (OMP) serta operasi militer selain }\end{array}$ & $\begin{array}{l}\text { a. Kesiapan personil, kemampuan dan } \\
\text { kualitas aparat kodim sangat diterima oleh } \\
\text { pemda dan masyarakat. }\end{array}$ \\
\hline perang (OMSP), didalam tugas operasi militer selain & b. Peluang saat ini memang hanya TNI \\
\hline tunya adalah me & yang siap \\
\hline Menjaga Stabilitas Pembangunan Di Era Adaptasi & dimanapun bencana pandemi Covid-19 terjadi. \\
\hline Kebiasaan Baru, dengan telah diundang- & Hal ini merupakan nilai jual TNI khususnya \\
\hline undangkannya tugas TNI maka dalam pelaksanaan & Kodim dalam memberik \\
\hline tugasnya TNI telah memiliki landasan hukum & political stakeholder atau \\
\hline kuat dan menyeluruh sesuai perkembangan maupun & di daerah untuk memberikan legislasi hukum \\
\hline $\begin{array}{l}\text { kebutuhan pelaksanaan tugas di wilayah tanggung } \\
\text { jawab masing-masing. }\end{array}$ & $\begin{array}{l}\text { bagi anggota Kodim agar terlibat aktif tidak } \\
\text { hanya sebatas sebagai tim pelaksana pada saat }\end{array}$ \\
\hline $\begin{array}{l}\text { b. Penggunaan kekuatan Kodim dalam } \\
\text { membantu menanggulangi pandemi Covid-19 dan } \\
\text { pemberian bantuan kemanusiaan yang bertujuan } \\
\text { mencegah berkembangnya kerugian, baik jiwa }\end{array}$ & $\begin{array}{l}\text { tanggap bencana pandemi Covid-19 namun } \\
\text { juga diharapkan dapat lebih berperan pada saat } \\
\text { masa pra-bencana dan pasca bencana melalui } \\
\text { metode binternya Dalam Menjaga Stabilitas }\end{array}$ \\
\hline $\begin{array}{l}\text { maupun harta benda rakyat dan membantu } \\
\text { mengatasi kesulitan rakyat agar tidak menimbulkan }\end{array}$ & $\begin{array}{l}\text { Pembangunan Di Era Adaptasi Kebiasaan } \\
\text { Baru. }\end{array}$ \\
\hline akibat yang mengancam kedaulatan negara dan & c. \\
\hline bangsa dilaksanakan melalui & peningkatan penanganan dan \\
\hline kemampuan pembinaan teritorial dan dukungan. & disiplin masyarakat di era $\mathrm{AKB}$, untuk \\
\hline $\begin{array}{l}\text { Beberapa kasus pandemi Covid-19 yang terjadi di } \\
\text { Daerah yang merupakan permasalahan yang harus }\end{array}$ & $\begin{array}{l}\text { peningkatan } \\
\text { Batam. }\end{array}$ \\
\hline ditangani oleh pemerintah Daerah keterlibatan TNI- & Ancaman \\
\hline AD khususnya Kodim sesuai peran, fungsi, dan & Kesiapan personil, kondisi lingkungan \\
\hline $\begin{array}{l}\text { tugas baik tugas bantuan pada pemerintah maupun } \\
\text { tugas dalam membantu kesulitan rakyat diantaranya }\end{array}$ & $\begin{array}{l}\text { dan Pendidikan yang kurang baik bias } \\
\text { mempengaruhi kualitas personel. }\end{array}$ \\
\hline tugas membantu menanggulangi pandemi Covid-19 & Kesiapan sarana dan prasarana, \\
\hline $\begin{array}{l}\text { dan bantuan kemanusiaan Dalam Menjaga Stabilitas } \\
\text { Pembangunan Di Era Adaptasi Kebiasaan Baru. }\end{array}$ & $\begin{array}{l}\text { kurangnya pemeliharaan alat-alat dapat } \\
\text { mempengaruhi kualitas sarana dan prasarana } \\
\text { yang ada.. }\end{array}$ \\
\hline 2.Kelemahan & Belum jelasnya penataan penempatan \\
\hline a. Belum & struktur organisasi untuk keterlibatan TNI pada \\
\hline $\begin{array}{l}6 \text { tahun } 2020 \text { dalam membuat aturan pelaksanaan } \\
\text { berupa perkada atau peraturan Walikota yang }\end{array}$ & $\begin{array}{l}\text { penanggulangn bencana pandemi Covid-19 di } \\
\text { daerah yang dapat menyebabkan sulitnya }\end{array}$ \\
\hline
\end{tabular}




\begin{tabular}{|c|c|}
\hline Faktor Internal & Faktor Eksternal \\
\hline $\begin{array}{l}\text { menjadi dasar pelaksanaan dalam mengantisipasi } \\
\text { AKB di Kota Batam. } \\
\text { B. Ditambah lagi Tingkat pendidikan formal } \\
\text { yang dimiliki sebagian besar aparat Kodim serta } \\
\text { minimnya pengetahuan teknis tentang } \\
\text { penanggulangan pandemi Covid-19 merupakan } \\
\text { suatu kelemahan. Hal ini akan berpengaruh terhadap } \\
\text { kualitas pencapaian sasaran seperti yang } \\
\text { diharapkan. } \\
\text { c. Sarana dan prasarana. Sarana dan } \\
\text { prasarana yang belum memadai atau masih terbatas, } \\
\text { harus dapat diantisipasi sebelum operasional } \\
\text { kegiatan agar disiapkan, sehingga tidak } \\
\text { menghambat dalam pelaksanaannya. Perlu diingat } \\
\text { bahwa batas kemampuan Kodim adalah untuk } \\
\text { menggelar operasi kemanusiaan yakni dari segi } \\
\text { mobilitas, kemampuan angkut, hospitalisasi dan } \\
\text { anggaran menjadikannya kelemahan dalam } \\
\text { penanganan penanggulangan pandemi Covid-19 di } \\
\text { daerah. Tidak terdapatnya Program pelatihan } \\
\text { d. } \\
\text { penanggulangan pandemi Covid-19 pada program } \\
\text { TNI khususnya di Kodim. } \\
\text { e. Tidak adanya BPBD sebagai OPD dalam } \\
\text { penanganan bencana, sehingga leading sector } \\
\text { penanganan bencana tidak ada. }\end{array}$ & $\begin{array}{l}\text { koordinasi dilapangan apabila } \\
\text { bencana alam sewaktu-waktu } \\
\text { terjadinya benturanger } \\
\text { seruran di lapangan. }\end{array}$ \\
\hline
\end{tabular}

Sumber : Data diolah peneliti 2020

Dari hasil analisis tersebut maka strategi yang harus dilakukan ialah :

1. Memaksimalkan pelatihan personil yang sudah terlatih, sehingga lebih siap

Dalam Menjaga Stabilitas Pembangunan Di Era Adaptasi Kebiasaan Baru;

2. Meningkatnya Sarana Prasarana yang telah ada Dalam Menjaga Stabilitas Pembangunan Di Era Adaptasi Kebiasaan Baru;

3. Meningkatkan sinergitas dan solidaritas melalui Komunikasi, Koordinasi dan Kolaborasi yang baik antara Kodim, Polres dan Pemda Dalam Menjaga Stabilitas Pembangunan Di Era Adaptasi Kebiasaan Baru;

4. Menindaklanjuti dari Inpres no 6 tahun 2020 dalam membuat aturan pelaksanaan berupa perkada atau peraturan Walikota yang menjadi dasar pelaksanaan dalam mengantisipasi AKB di Kota Batam;

5. Memberikan pembelajaran protocol kesehatan bagi masyarakat yang mendorong Stabilitas Pembangunan Di Era Adaptasi Kebiasaan Baru; 


\section{KESIMPULAN}

Peran Satkowil Bersama Komponen Bangsa Lainnya Dalam Menjaga Stabilitas Pembangunan Di Era Adaptasi Kebiasaan Baru, Peran Preventif dalam tindakan preventif satuan kodim sudah melakukan sosialisasi kepada masyarakat tentang kehidupan di era $\mathrm{AKB}$ dalam rangka menjaga stabilitas keberhasilan pembangunan nasional, Peran Persuasif Melalui tindakan persuasif satuan kodim dalam melakukan operasi penertiban dan penegakan disiplin masyarakat tentang kehidupan di era AKB dalam rangka menjaga stabilitas pembangunan nasional, Peran Represif Kodim 0316/Batam dalam menjaga dan memelihara kondusifitas pelaksanaan Pembatasan Sosial Berskala Besar (PSBB), melakukan pemberdayaan potensi wilayah sebagai bagian dari pembinaan dan pemberdayaan wilayah pertahanan, serta Peran Kuratif Kodim 0316/Batam mempunyai peran menskrining Covid-19 di wilayah kerjanya dengan bekerja sama dengan dokter praktik/klinik/bidan praktik. Mereka juga perlu memantau orang-orang tanpa gejala (OTG), orang dalam pemantauan (ODP) atau pasien dalam pengawasan (PDP) dengan gejala ringan.

Adapun rekomendasi sebagai berikut :

1. Memaksimalkan pelatihan personil yang sudah terlatih, sehingga lebih siap Dalam Menjaga Stabilitas Pembangunan Di Era Adaptasi Kebiasaan Baru;

2. Meningkatnya Sarana Prasarana yang telah ada Dalam Menjaga Stabilitas Pembangunan Di Era Adaptasi Kebiasaan Baru;

3. Meningkatkan sinergitas dan solidaritas melalui Komunikasi, Koordinasi dan Kolaborasi yang baik antara Kodim, Polres dan Pemda Dalam Menjaga Stabilitas Pembangunan Di Era Adaptasi Kebiasaan Baru;

4. Menindaklanjuti dari Inpres no 6 tahun 2020 dalam membuat aturan pelaksanaan berupa perkada atau peraturan Walikota yang menjadi dasar pelaksanaan dalam mengantisipasi AKB di Kota Batam;

5. Memberikan pembelajaran protocol kesehatan bagi masyarakat yang mendorong Stabilitas Pembangunan Di Era Adaptasi Kebiasaan Baru; 


\section{DAFTAR PUSTAKA}

Connie Rahakundini Bakrie, Pertahanan Negara dan Postur TNI Ideal, (Jakarta : Yayasan Obor Indonesia, 2007).

Effendy, Onong Unchjana. 2007. Strategi Komunikasi, Sebuah Pengantar Ringkas. Bandung : PT. Remaja Rosdakarya.

Ernan Rustiadi, Sunsun Saefulhakim, \& Dyah, R Panuju, 2009. Perencanaan dan pengembangan wilayah. Kerjasama Cresptent Press dan Yayasan Obor Indonesia, Anggota IKAPI DKI Jakarta.

Horton, Paul B.; Hunt, Chester L. 1993. Personal learning aid for introductory sociology. Edisi: ke-6 Penerbit: Jakarta: Erlangga.

Muhammad, Suwarsono. 2013. Strategi Pemerintahan, Manajemen Organisasi Publik. Jakarta : Erlangga.

Parthiana, I Wayan. 2003. Pengantar Hukum Internasional. Penerbit: CV Mandar Maju.

Rebecca M. Wallace. 2002. International Law, 4th edition, (London: Sweet \& Maxwel Ltd.

Soerjono Soekamto. 2017. Sosiologi Suatu pengantar. Edisi Revisi. Rajawali Pers. Jakarta.

Sugiyono. 2013. Memahami Penelitian Kualitatif. Bandung : Alfabeta.

Tikson, T. Deddy. 2005. Administrasi Pembangunan. Makassar : Gemilang. Persada.

\section{Dokumen :}

Undang-Undang Nomor 3 Tahun 2003 tentang Pertahanan Negara.

Undang-Undang Nomor 34 Tahun 2004 tentang Tentara Nasional Indonesia.

Undang-Undang Nomor 24 Tahun 2007 tentang penanggulangan bencana.

Undang - Undang Nomor 23 tahun 2014 tentang Pemerintahan Daerah.

Peraturan Pemerintah Republik Indonesia Nomor 21 Tahun 2020 tentang Pembatasan Sosial Berskala Besar dalam Rangka Percepatan Pembangunan Corona Virus Disease 2019 (Covid-19). 
Peraturan Menteri Kesehatan Republik Indonesia Nomor 9 Tahun 2020 tentang Pedoman Pembatasan Sosial Berskala Besar dalam rangka percepatan penanganan Corona Virus Disease 2019 (Covid-19).

Keputusan Presiden Republik Indonesia Nomor 11 Tahun 2020 tentang Penetapan Kedaruratan Kesehatan Masyarakat Corona Virus Disease 2019 (Covid19).

Keputusan Presiden Republik Indonesia Nomor 9 Tahun 2020 tentang Perubahan atas Keputusan Presiden Nomor 7 Tahun 2020 tentang Gugus Tugas Percepatan penanganan Corona Virus Disease 2019 (Covid-19).

Peraturan Presiden Republik Indonesia Nomor 82 Tahun 2020 tentang Komite Penangnan Corona Virus Disease 2019 (Covid-19) dan pemulihan ekonomi nasional.

Permenhan RI No. 40 Tahun 2011, tentang Kebijakan Pemberdayaan Wilayah Pertahanan.

Keputusan Walikota Batam Nomor KPTS. 252/HK/IV/2020 tentang Status Tanggap Darurat Bencana Non Alam Wabah Penyakit Akibat Virus Corona (Covid-19) di Kota Batam.

Keputusan Walikota Batam Nomor : KPTS. 258/HK/III/2020 tentang Gugus Tugas Percepatan Penanganan Corona Virus Disease 2019 (Covid-19) tingkat Kota Batam.

Keputusan Walikota Batam Nomor KPTS. 261/HK/IV/2020 tentang Besaran Insentif/Honorarium Tenaga Kesehatan, Tenaga Pendukung dan Kompensasi Penanganan Covid-19 di Kota Batam Tahun 2020.

Keputusan Walikota Batam Nomor KPTS. 264/HK/IV/2020 tentang Penunjukan Satuan Kerja Perangkat Daerah/Instansi Vertikal dan Pembebanan Anggaran Belanja Tidak Terduga Kepada Satuan Kerja Perangkat Daerah/Instansi Vertikal Terkait Pencegahan Penyebaran dan Percepatan Penanganan Corona Virus Disease 2019 (COVID 2019) di Kota Batam Tahap I.

Keputusan Walikota Batam Nomor KPTS. 266/HK/IV/2020 tentang Penetapan Rumah Susun di Bawah Pengelolaan Dinas Perumahan Rakyat Permukiman dan Pertamanan Kota Batam sebagai Tempat Isolasi Covid19.

Keputusan Walikota Batam Nomor KPTS. 267/HK/IV/2020 tentang Penunjukan Satuan Kerja Perangkat Daerah/Instansi Vertikal dan Pembebanan Anggaran Belanja Tidak Terduga Kepada Satuan Kerja Perangkat 
Daerah/Instansi Vertikal Terkait Pencegahan Penyebaran dan Percepatan Penanganan Corona Virus Disease 2019 (COVID 2019) di Kota Batam Tahap II. 